\title{
Micro-behavioral Study of Bagasse Ash based Geopolymer Concrete
}

\author{
Savitha T M, Y M Manjunath, Dilip Srinivas
}

\begin{abstract}
Cement manufacturing industries which emits about $7 \%$ of $\mathrm{CO}_{2}$ to the environment causing pollution. So, in order to avoid pollution problems there is a need to find an alternative binding material. Wastes like agricultural or industrial in the form of ash can be utilized as a substitute for cement. In this research work, Ground Granulated Blast-furnace Slag(GGBS) and Sugarcane Bagasse ash $(S C B A)$ is used as a complete replacement to cement so as to form Geopolymer concrete(GPC). Two different SCBA sources which has high amount of silica content is considered for the partial replacement of GGBS in varying percentages like $5 \%$, $10 \%, 15 \%, 20 \%, 25 \%, 30 \%$ to determine mechanical and microstructure properties. A 5 M alkaline solutions of Sodium hydroxide and Sodium silicate is used. In this work, mechanical properties of GGBS-SCBA based GPC which includes compressive strength, split tensile strength, flexural strength and microstructure properties of SCBA samples by $X$-ray Fluorescence (XRF), Energy Dispersive spectroscopy(EDS), X-ray Diffractometer(XRD), Scanning Electronic Microscope(SEM) techniques are determined and analyzed on different GPC mix proportions.
\end{abstract}

Index terms: Geopolymer concrete, Ground Granulated Blast-furnace Slag, Strength, Sugarcane Bagasse ash.

\section{INTRODUCTION}

At present, India faces waste management problem in every field, which is one of the major issues for the developing country [1]. India is an agricultural country \& its main economy is depending on agriculture[1]. Brazil is in the first place to produce more sugarcane, next to Brazil; India is the second largest sugarcane producing country[1]. Today in India there are 453 sugar mills which consists of 252 mills of co-operative sector and 134 mills of private sector. It is estimated that in India sugarcane production during the period of 2017-18 is reached to 32.25 million tonnes. In India top sugarcane producing states are Uttar Pradesh, Maharashtra, Karnataka and Tamil Nadu. Table 1 shows the sugarcane production in various states of India during the year 2017-18.

Revised Manuscript Received on July 05, 2019.

Savitha T M, is pursuing M. Tech. degree in Structural Engineering from National Institute of Engineering (NIE), Mysore, Karnataka, 570008, India.

Dr. Y. M. Manjunath, is working as a Professor in Department of Civil Engineering, National Institute of Engineering (NIE), Mysore, Karnataka, 570008, India.

Dilip Srinivas, working as Assistant Manager in L \& T CTEA, Mysore, Karnataka, India.
Table 1. Production of sugarcane in various states of India during 2017-18

\begin{tabular}{|c|c|}
\hline $\begin{array}{c}\text { Sugarcane } \\
\text { producing states in } \\
\text { India }\end{array}$ & $\begin{array}{c}\text { Production of sugarcane in } \\
\text { the year 2017-18(lakh } \\
\text { tonnes) }\end{array}$ \\
\hline Uttar Pradesh & 120.5 \\
\hline Maharashtra & 107.15 \\
\hline Karnataka & 36.54 \\
\hline Tamil Nadu & 6.0 \\
\hline
\end{tabular}

Geopolymer concrete is one of the best solutions. It was first introduced by Prof. T. Davidovits to characterize mineral polymers described by networks of inorganic molecules[2]. Geopolymer is resulting from the reaction between alumina-silicates and alkaline solution of Sodium hydroxide $(\mathrm{NaOH})$ and Sodium silicate $\left(\mathrm{Na}_{2} \mathrm{SiO}_{3}\right.$ [3]. Waste by-products of industries like fly-ash, GGBS, silica fume can be utilized to produce Geopolymer concrete[4]. For nation's economy, construction industry plays an important role. In the construction, utilization of agricultural or industrial by-products could become an important route for large scale safe disposal of wastes $\&$ there is a reduction of construction costs[5].

The objective of this work is to find the optimal replacement level of GGBS by SCBA sources and to analyze the microstructure of SCBA samples and GPC.

\section{MATERIALS AND METHODOLOGY}

\section{A. Materials}

The ingredients of GPC are GGBS, SCBA, fine and coarse aggregates, $\mathrm{NaOH}$ and $\mathrm{Na}_{2} \mathrm{SiO}_{3}$. GGBS and SCBA were the supplementary cementitious materials in GPC. GGBS is a by-product from thermal steel plants. It is collected from JSW cements, Mysore with loss of ignition 0.08, with specific gravity 2.92 and fineness $6 \%$. SCBA is an agricultural waste material obtained by burning the bagasse, where bagasse is a fibrous residue after extracting juice from sugarcane during the production of sugar. The sources which are considered for the study are named as GGBS, SCBA-1 and SCBA-2. 


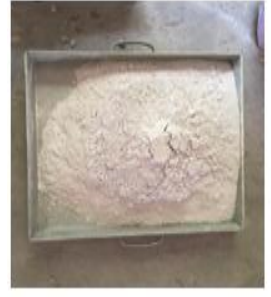

GGBS

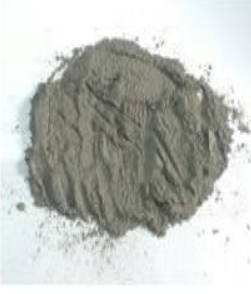

SCBA-1

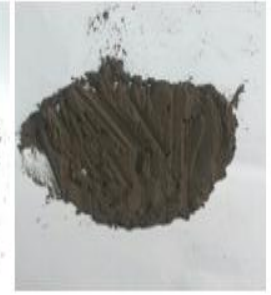

SCBA-2
Fig 1. Appearance of GGBS, SCBA-1, SCBA-2

Figure 1 shows the physical appearance of GGBS, SCBA-1 and SCBA-2. $10 \mathrm{~mm}$ and $20 \mathrm{~mm}$ downsize coarse aggregates and fine aggregates were used. Manufactured sand is used as fine aggregate instead of natural sand because natural sand has become expensive and scarce. $\mathrm{NaOH}$ and $\mathrm{Na}_{2} \mathrm{SiO}_{3}$ are used as alkaline activator. $\mathrm{NaOH}$ is purchased in the form of pellets and dissolved in distilled water for $5 \mathrm{M}$ concentration. $\mathrm{Na}_{2} \mathrm{SiO}_{3}$ is in semi liquid form.

\section{B. Methodology}

a) Preliminary tests on aggregates being carried out for M-sand, $10 \mathrm{~mm}$ and $20 \mathrm{~mm}$ downsize aggregates. Table 2 shows the physical properties of coarse aggregates and fine aggregates. These tests results are confirming to IS:383-1970.

Table 2. Physical properties of aggregates

\begin{tabular}{|c|c|c|c|}
\hline $\begin{array}{c}\text { Physical } \\
\text { properties }\end{array}$ & $\begin{array}{c}\mathbf{2 0} \mathbf{~ m m} \\
\text { size }\end{array}$ & $\begin{array}{c}\mathbf{1 0 m m} \\
\text { size }\end{array}$ & M-sand \\
\hline Specific Gravity & 2.60 & 2.62 & 2.51 \\
\hline Fineness modulus & 7.6 & 7.301 & 3.50 \\
\hline Bulk density & \multicolumn{3}{|l}{} \\
\hline $\begin{array}{c}\text { Loose sand } \\
\left(\mathbf{K g} / \mathbf{m}^{3}\right)\end{array}$ & $\begin{array}{c}1264.1 \\
9\end{array}$ & 1353.31 & $\begin{array}{c}1317.5 \\
3\end{array}$ \\
\hline $\begin{array}{c}\text { Compacted sand } \\
\left(\mathbf{K g} / \mathbf{m}^{3}\right)\end{array}$ & $\begin{array}{c}1479.1 \\
9\end{array}$ & 1534.16 & $\begin{array}{c}1572.9 \\
6\end{array}$ \\
\hline Water absorption & $1.6 \%$ & $1.4 \%$ & $1.25 \%$ \\
\hline
\end{tabular}

b) Preliminary tests on source materials [SCBA and GGBS] is being carried out such as specific gravity and fineness of the sample. Table 3 shows the physical properties of GGBS, SCBA-1 and SCBA-2. Fineness of SCBA- 1 and SCBA-2 is found to be $62 \%$ and $54 \%$ respectively. Fineness of SCBA is more because of the presence of coarser particle in it.

Table 3. Physical properties of GGBS, SCBA-1 \& SCBA-2 as per IS 1727-1967

\begin{tabular}{|l|c|c|}
\hline $\begin{array}{c}\text { Test } \\
\text { nducted }\end{array}$ & ppecific Gravity & ineness of SCBA \\
\hline GGBS & 2.92 & $6 \%$ \\
\hline SCBA-1 & 0.32 & 0.41 \\
\hline SCBA-2 & $62 \%$ & $54 \%$ \\
\hline
\end{tabular}

c) Design mix for the GPC for the grade of M30 mix is adopted as per B.V. Rangan method.

d) $\mathrm{NaOH}$ solutions is prepared for $5 \mathrm{M}$ concentration. e) Alkaline solution is prepared by adding $\mathrm{Na}_{2} \mathrm{SiO}_{3}$ solution to the $\mathrm{NaOH}$ solutions before 30 minutes of casting.

f) Test specimens are prepared for various GPC mixes.

g) The trial mixes are carried out for 5\%SCBA-1 +95\%GGBS and 5\% SCBA-2+95\% GGBS.

h) The test specimens like cubes, cylinders and beams with different SCBA sources for $5 \mathrm{M}$ concentration are casted for various mixes like

- $\mathrm{M} 1$ - 5\%SCBA+95\%GGBS

- $\mathrm{M} 2$ - 10\%SCBA+90\%GGBS

- $\mathrm{M} 3$ - $15 \% \mathrm{SCBA}+85 \% \mathrm{GGBS}$

- M4 - 20\%SCBA+80\%GGBS

- M5 - 25\%SCBA+75\%GGBS

- M6 - 30\%SCBA+70\%GGBS

i) The test specimens were exposed to the sunlight for the sunlight curing.

j) The results such as compressive strength, split tensile strength and flexural strength are tabulated for cubes, cylinders and beams respectively.

k) The economic replacement is being carried forward to analyse the microstructure of GPC with SCBA-1 and GPC with SCBA-2. Then by using SEM, microstructure analysis is carried out.

1) XRF, XRD, SEM, EDS analysis is carried out to study the microstructure of SCBA-1 and SCBA-2 samples.

\section{Preparation of Alkaline solution}

Alkaline solution is prepared by using $\mathrm{NaOH}$ and $\mathrm{Na}_{2} \mathrm{SiO}_{3}$ in the ratio of $1: 2.5$. A $5 \mathrm{M}$ of $\mathrm{NaOH}$ solution is prepared by dissolving $200 \mathrm{gms}$ of $\mathrm{NaOH}$ pellets in distilled water. It is prepared one day before casting and after 24 hours, $\mathrm{Na}_{2} \mathrm{SiO}_{3}$ solution is added to the $\mathrm{NaOH}$ solution to form alkaline solution. Figure 2 shows the preparation of alkaline solution.

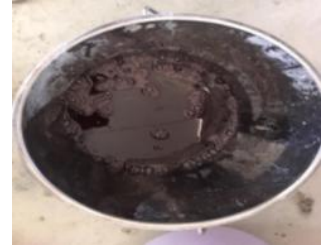

Fig 2. Preparation of alkaline solutions

\section{Mixing Procedure and Curing}

For M30 grade, GPC mix is prepared. Mix design is followed as per B.V. Rangan paper. There are 6 GPC mixes developed by varying the percentage replacement of GGBS by different sources of bagasse ash. Mix proportions are shown in table $4 \mathrm{a}$ and $4 \mathrm{~b}$.

Table 4a. Mix proportions

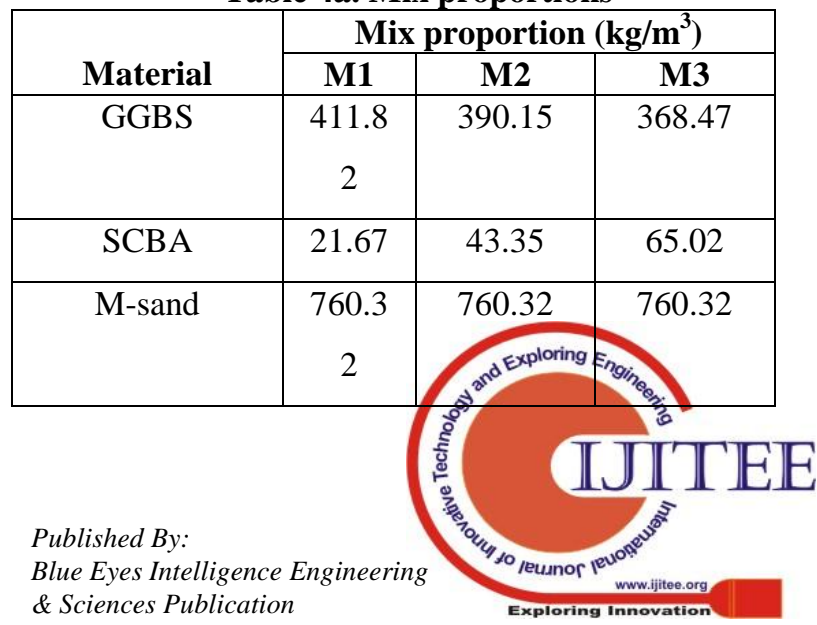




\begin{tabular}{|c|c|c|c|}
\hline $20 \mathrm{~mm}$ aggregate & $\begin{array}{c}483.8 \\
4\end{array}$ & 483.84 & 483.84 \\
\hline $10 \mathrm{~mm}$ aggregate & $\begin{array}{c}483.8 \\
4\end{array}$ & 483.84 & 483.84 \\
\hline $\mathrm{NaOH}$ molarity & $5 \mathrm{M}$ & $5 \mathrm{M}$ & $5 \mathrm{M}$ \\
\hline $\mathrm{NaOH}$ & 68.12 & 68.12 & 68.12 \\
\hline $\mathrm{Na}_{2} \mathrm{SiO}_{3}$ & $\begin{array}{c}170.3 \\
2\end{array}$ & 170.32 & 170.32 \\
\hline Water & 75.00 & 75.00 & 75.00 \\
\hline
\end{tabular}

Table 4b. Mix proportions

\begin{tabular}{|c|c|c|c|}
\hline \multirow[b]{2}{*}{ Material } & \multicolumn{3}{|c|}{ Mix proportion $\left(\mathrm{kg} / \mathrm{m}^{3}\right)$} \\
\hline & M4 & M5 & M6 \\
\hline GGBS & 346.80 & 325.12 & 303.45 \\
\hline SCBA & 86.70 & 108.37 & 130.05 \\
\hline M-sand & 760.32 & 760.32 & 760.32 \\
\hline $20 \mathrm{~mm}$ aggregate & 483.84 & 483.84 & 483.84 \\
\hline $10 \mathrm{~mm}$ aggregate & 483.84 & 483.84 & 483.84 \\
\hline $\mathrm{NaOH}$ molarity & $5 \mathrm{M}$ & $5 \mathrm{M}$ & $5 \mathrm{M}$ \\
\hline $\mathrm{NaOH}$ & 68.12 & 68.12 & 68.12 \\
\hline $\mathrm{Na}_{2} \mathrm{SiO}_{3}$ & 170.32 & 170.32 & 170.32 \\
\hline Water & 75.00 & 75.00 & 75.00 \\
\hline
\end{tabular}

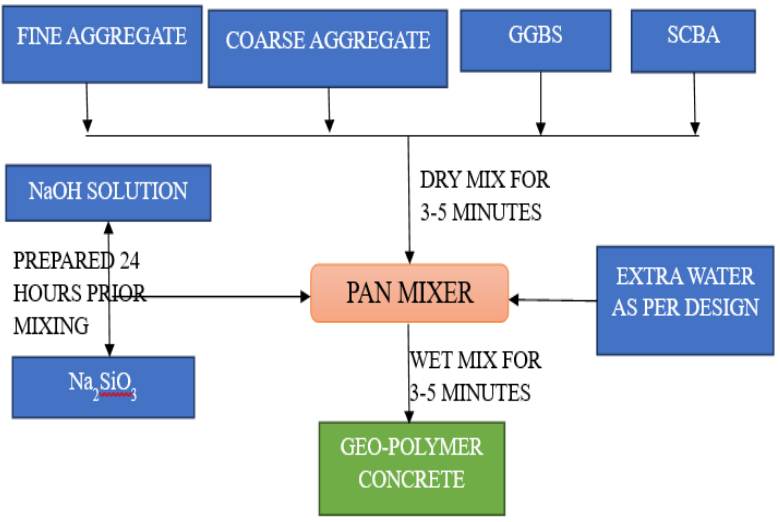

Fig 3. Flowchart of mixing process of GPC

Figure 3 shows the mixing procedure of GPC. First batching of materials like GGBS, SCBA, fine aggregate and coarse aggregate is done. These materials poured into pan mixer and dry mixed for about 3-5 minutes as shown in figure 4.

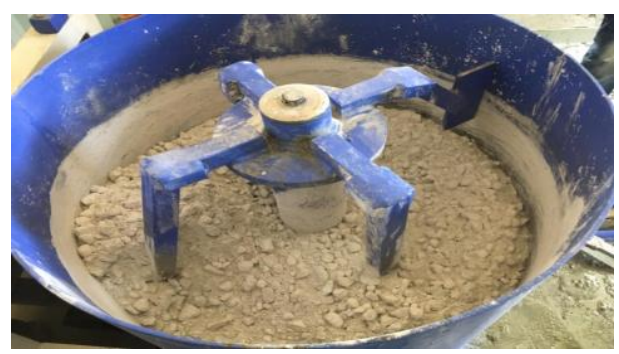

Fig 4. Dry mixing of ingredients
Then for this mixture alkaline solution and water is added and mixed for about 3-5 minutes as shown in figure 5 .

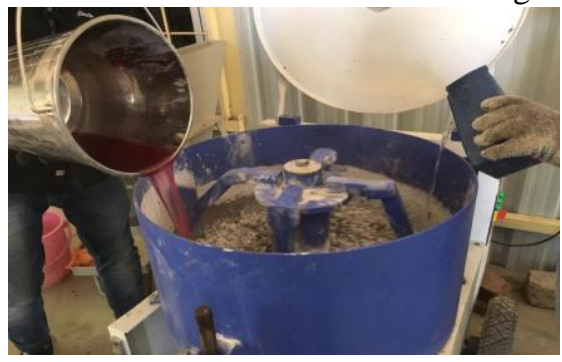

Fig 5. Addition of alkaline solution and water

After proper mixing, the GPC is filled into appropriate moulds of cubes, beams and cylinders shown in figure 6 . Figure 7 shows the casted specimens kept outside the lab for sun light curing.

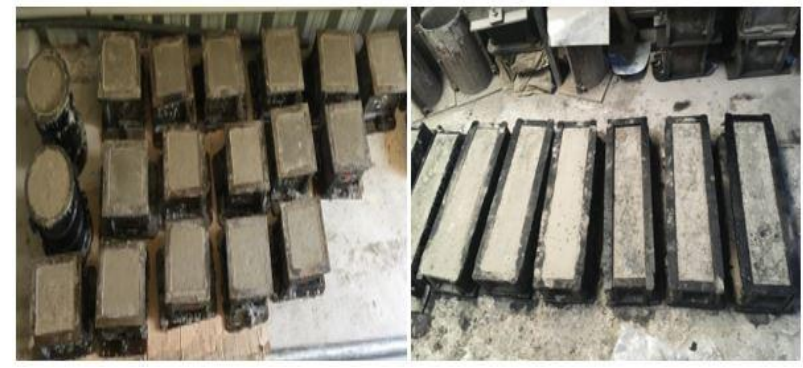

Fig 6. casted specimens

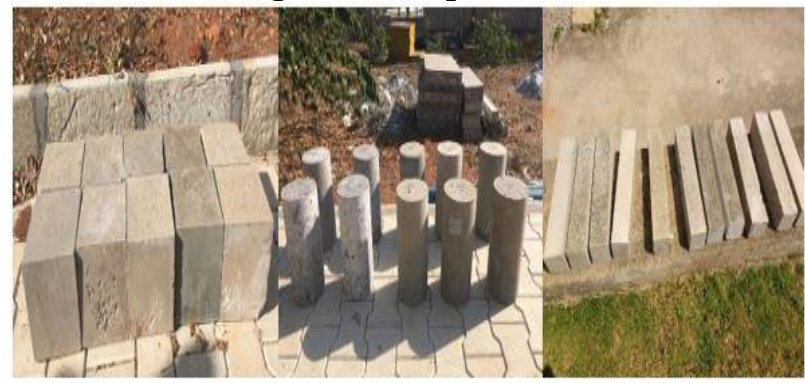

Fig 7. sunlight curing of casted specimens

\section{E. Experimental execution}

The compressive, split tensile and flexural strength is determined for all 6 GPC mixes. XRF, XRD, EDS and SEM analysis were carried out for SCBA-1 and SCBA-2 source samples. For GPC mix with highest strength is considered for SEM analysis of GPC. The cube of size $150 \mathrm{mmX} 150 \mathrm{mmX} 150 \mathrm{~mm}$, cylindrical specimen of $150 \mathrm{~mm}$ diameter and $300 \mathrm{~mm}$ height, beam of $100 \mathrm{~mm} \times 100 \mathrm{~mm} \times 500 \mathrm{~mm}$ is used.

Cubes are cured for a period of 7 and 28 days. Cylinders and beams are cured for 28 days. Cubes and cylinders were tested by $2000 \mathrm{kN}$ capacity compression testing machine as per IS:516-1959 and IS:5816-1999. Beams are tested by Universal testing machine as per IS:516-1959.

\section{RESULTS AND DISCUSSIONS}

\section{A. XRF Analysis}

Chemical composition of GGBS and SCBA is 


\section{Micro-behavioral study of Bagasse ash based Geopolymer concrete}

determined by XRF analysis. These results confirm as per IS:16714-2018 specifications. Table 5 shows the chemical composition of GGBS and it is observed that GGBS consists of $88.7 \%$ of glass content.

Table 5. chemical composition of GGBS

\begin{tabular}{|c|c|}
\hline Test Conducted & Results (\%) \\
\hline Manganese oxide $(\mathrm{MnO})$ & 0.07 \\
\hline Magnesium oxide $(\mathrm{MgO})$ & 7.07 \\
\hline Sulfide sulphur $(\mathrm{S})$ & 0.47 \\
\hline Sulphate $\left(\mathrm{SO}_{3}\right)$ & 0.18 \\
\hline Insoluble residue $(\mathrm{Max})$ & 0.78 \\
\hline Chloride content & 0.02 \\
\hline Loss on ignition & 0.08 \\
\hline Glass content & 88.70 \\
\hline
\end{tabular}

Table 6 shows 9 different SCBA samples collected from different places in Karnataka with varying silica content. It is seen that SCBA-1 and SCBA-2 contains highest silica content. So, these two sources of SCBA is considered for the further study.

Table 6. chemical composition of different SCBA sources

\begin{tabular}{|c|c|c|}
\hline $\begin{array}{c}\text { SCBA } \\
\text { samples }\end{array}$ & Location & $\begin{array}{c}\text { Silica } \\
\text { content( } \\
\%)\end{array}$ \\
\hline SCBA-1 & Shamboonalli Aalemane 1 & 76.06 \\
\hline SCBA-2 & Shamboonalli Aalemane 2 & 72.89 \\
\hline SCBA-3 & Bannur Aalemane & 64.35 \\
\hline SCBA-4 & $\begin{array}{c}\text { Srirangapattana Sugar } \\
\text { factory }\end{array}$ & 60.78 \\
\hline SCBA-5 & K.R. Nagara Aalemane 1 & 49.73 \\
\hline SCBA-6 & K.R. Nagara Aalemane 2 & 67.78 \\
\hline SCBA-7 & K.R. Nagara Aalemane 3 & 53.81 \\
\hline
\end{tabular}

Table 7. chemical composition of SCBA-1 \& SCBA-2

\begin{tabular}{|c|c|c|}
\hline Test & SCBA-1(\%) & $\begin{array}{c}\text { SCBA-2 } \\
(\%)\end{array}$ \\
\hline Silicon as $\mathbf{S i O}_{\mathbf{2}}$ & 72.89 & 76.06 \\
\hline Iron as $\mathbf{F e}_{\mathbf{2}} \mathbf{O}_{\mathbf{3}}$ & 2.34 & 5.60 \\
\hline Aluminium as $\mathbf{A l}_{2} \mathbf{O}_{\mathbf{3}}$ & 3.65 & 4.94 \\
\hline Calcium as CaO & 4.55 & 1.86 \\
\hline Magnesium as MgO & 2.55 & 1.48 \\
\hline Sodium as $\mathbf{N a}_{2} \mathbf{O}$ & 0.76 & 0.55 \\
\hline Potassium as $\mathbf{K}_{\mathbf{2}} \mathbf{O}$ & 5.05 & 1.77 \\
\hline LOI & 0.52 & 0.71 \\
\hline
\end{tabular}

Table 7 shows the chemical composition of SCBA-1 and SCBA-2. As per ASTM C 618, LOI $<10 \%$ and $\mathrm{SiO}_{2}+\mathrm{Al}_{2} \mathrm{O}_{3}$ $+\mathrm{Fe}_{2} \mathrm{O}_{3}>70 \%$. It is observed from the Table 7 that LOI is within the limits and for SCBA-1, sum of $\mathrm{SiO}_{2}+\mathrm{Al}_{2} \mathrm{O}_{3}$ $+\mathrm{Fe}_{2} \mathrm{O}_{3}=78.88 \%>70 \%$ and for SCBA-2, sum of $\mathrm{SiO}_{2}+$ $\mathrm{Al}_{2} \mathrm{O}_{3}+\mathrm{Fe}_{2} \mathrm{O}_{3}=86.61 \%>70 \%$.

\section{B. XRD analysis}

Mineralogical examination of SCBA is completed by XRD analysis. From XRD graphs it is observed that intensity changes continuously and $2 \theta$ also gradual changes. In order to conduct XRD analysis, the SCBA is sieved through $90 \mu \mathrm{m}$ sieve and then the samples are tested in the laboratory by using XRD equipment. In the present study, SCBA is scanned from $10^{\circ}$ to $70^{\circ}$. The results obtained are then plotted to graphs by using Origin Pro-2018 software. This software is mainly used for graphing and analysis.

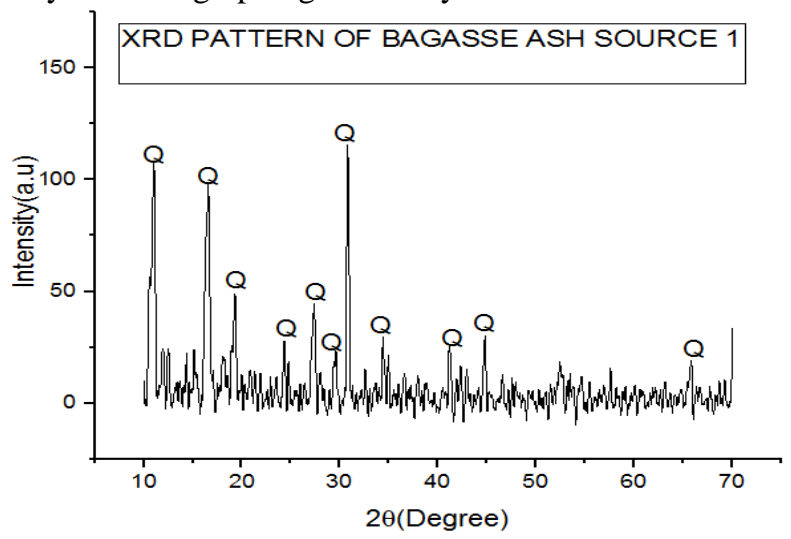

Fig 8. XRD pattern of SCBA-1

Figure 8 and 9 shows the XRD pattern of SCBA-1 and SCBA-2 respectively. It is said that pozzolanic activity depends on the presence of amorphous silica rather than crystalline silica. It can be detected from the graph in figure 8 that the SCBA-1 contains silica in the form of Quartz. Highest peaks are observed at the diffraction angle of $11^{\circ}, 16^{\circ}$ and $31^{\circ}$.

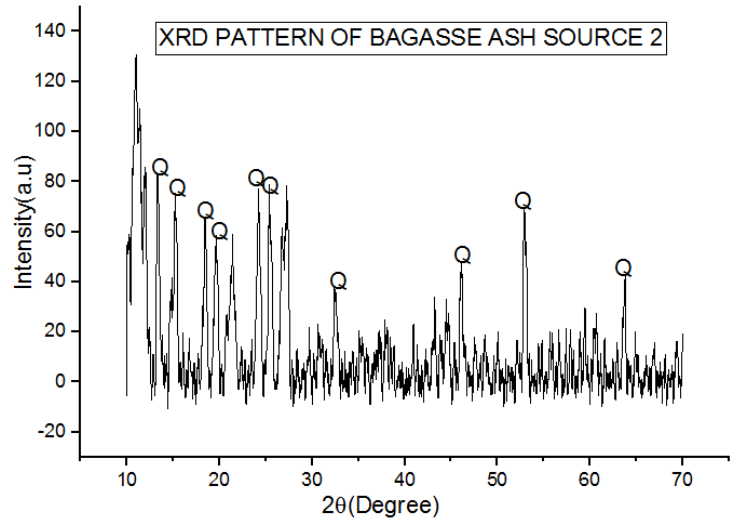

Fig 9. XRD pattern of SCBA-2

From the graph in figure 9 it can be witnessed that multiple peaks shows the presence of Quartz. Highest peaks are observed at the diffraction angle between $10^{\circ}$ and $30^{\circ}$. But after $30^{\circ}$ also peaks of Quartz are observed. Some peaks are deviated from the baseline in SCBA-2 which represents the presence of amorphous constituents that seen as broad peaks between $10^{\circ}$ and $15^{\circ}$ and also between $20^{\circ}$ and $25^{\circ}$ these represent the presence of reactive silica.

\section{SEM and EDS Analysis}

By using SEM, the morphology of SCBA is determined. Elemental composition is determined 
by EDS analysis. In order to know the characterization and identification of minerals present in SCBA and morphology of SCBA, SEM with EDS analysis is carried out.

(a) SCBA-1

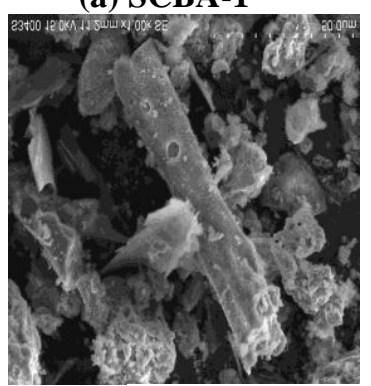

Fig 10. SEM images of SCBA-1 and SCBA-2

In figure 10 (a), the morphology of SCBA-1 is seen which shows that the particles are less dense, it contains crystalline and prismatic particles. In figure 10(b), the morphology of SCBA-2 is seen which shows that the particles are denser.

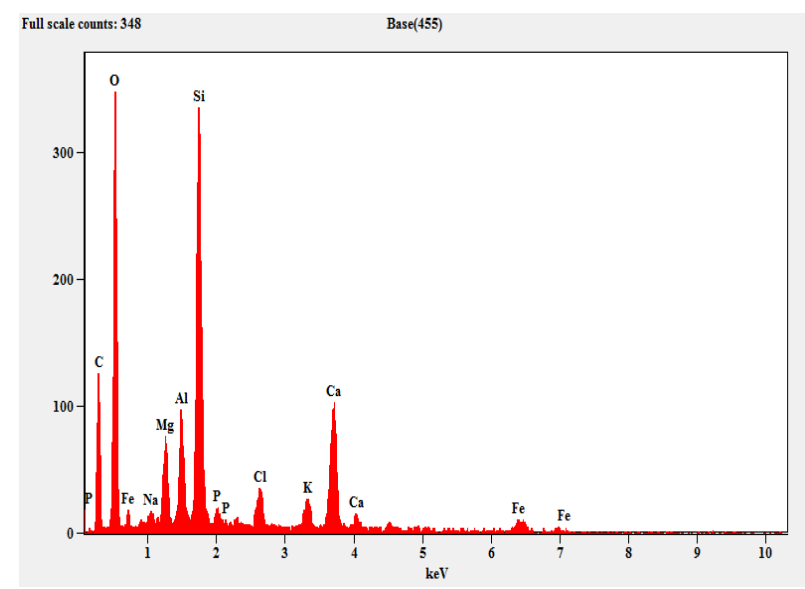

Fig 11. EDS analysis of SCBA-1

Figure 11 shows the EDS analysis results, from which it is observed that SCBA-1 contains large amount of Silica (Si), oxygen $(\mathrm{O})$, Aluminum( $\mathrm{Al})$, Magnesium(Mg), Carbon(C), Calcium $(\mathrm{Ca})$ and lesser amount of $\operatorname{Potassium}(\mathrm{K})$, Sodium(Na), Chloride $(\mathrm{Cl}), \quad$ Titanium(Ti), Iron $(\mathrm{Fe})$, Phosphorus $(\mathrm{P})$. The Elemental composition of SCBA-1 is shown in table 8 which shows similar composition but there is some variation in the proportions.

Table 8. Elemental composition of SCBA-1

\begin{tabular}{|c|c|}
\hline Element & BA-1 (weight \%) \\
\hline $\mathrm{Si}$ & 7.83 \\
\hline $\mathrm{O}$ & 45.32 \\
\hline $\mathrm{Mg}$ & 1.36 \\
\hline $\mathrm{Al}$ & 1.85 \\
\hline $\mathrm{P}$ & 0.43 \\
\hline $\mathrm{Cl}$ & 1.28 \\
\hline $\mathrm{K}$ & 1.10 \\
\hline $\mathrm{Ca}$ & 4.70 \\
\hline $\mathrm{Fe}$ & 1.56 \\
\hline $\mathrm{C}$ & 34.56 \\
\hline
\end{tabular}

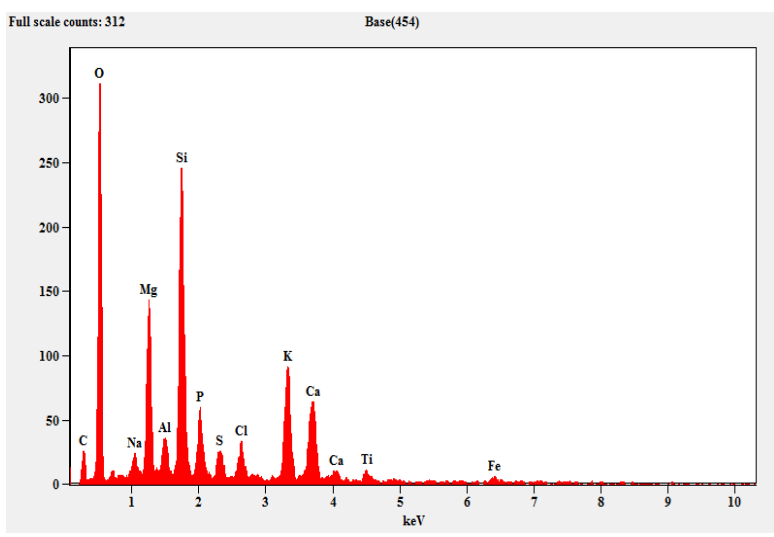

Fig 12 EDS analysis of SCBA-2

Figure 12 shows the EDS analysis results, from which it can be observed that SCBA-2 contains large amount of Silica( $\mathrm{Si})$, oxygen $(\mathrm{O})$, Magnesium(Mg), Calcium(Ca), Potassium(K) and lesser amount of Sodium(Na), Aluminum(Al), Sulphur, Chloride $(\mathrm{Cl})$, Titanium(Ti) and $\operatorname{Iron}(\mathrm{Fe})$, Phosphorus $(\mathrm{P})$ and carbon. . The Elemental composition of SCBA-2 is shown in table 9 .

Table 9. Elemental composition of SCBA-2

\begin{tabular}{|c|c|}
\hline Element & BA-2 (weight \%) \\
\hline $\mathrm{Si}$ & 14.73 \\
\hline $\mathrm{O}$ & 1.385 \\
\hline $\mathrm{Na}$ & 0.91 \\
\hline $\mathrm{Mg}$ & 7.05 \\
\hline $\mathrm{Al}$ & 1.82 \\
\hline $\mathrm{P}$ & 5.14 \\
\hline $\mathrm{S}$ & 2.58 \\
\hline $\mathrm{Cl}$ & 2.67 \\
\hline $\mathrm{K}$ & 9.52 \\
\hline $\mathrm{Ca}$ & 8.82 \\
\hline $\mathrm{Ti}$ & 2.07 \\
\hline $\mathrm{Fe}$ & 2.84 \\
\hline $\mathrm{C}$ & 40.45 \\
\hline
\end{tabular}

\section{Workability of GPC}

On fresh concrete in order to know the effect of inclusion of SCBA in GPC, it is tested for slump. The workability for GPC is tested as per IS 1199-195.

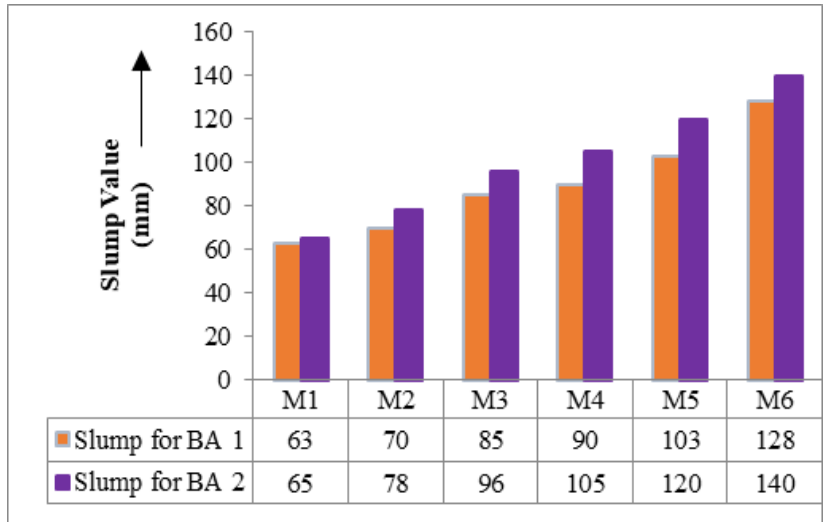

Fig 13. workability of GPC mix

From the figure 13 it is detected that the workability of GPC decreased as the percentage inclusion of SCBA is increased in the mix because

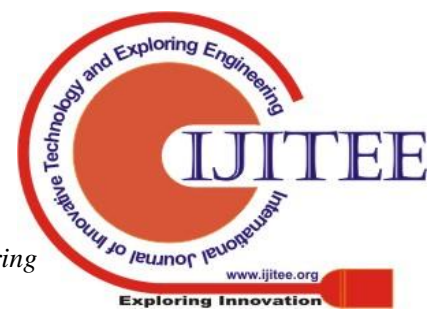


when SCBA is added to the mix it absorbs water.

\section{E. Compressive strength test}

Compressive strength test for GGBS with SCBA-1 based GPC cubes is conducted at $7^{\text {th }}$ and $28^{\text {th }}$ days and the results are tabulated in table 10 .

Table 10. Compressive strength test results in MPa

\begin{tabular}{|c|c|c|}
\hline Mix ID & 7days & 28days \\
\hline M1 & 30.45 & 43.00 \\
\hline M2 & 28.75 & 41.04 \\
\hline M3 & 28.62 & 40.90 \\
\hline M4 & 27.93 & 40.11 \\
\hline M5 & 25.15 & 35.2 \\
\hline M6 & 23.06 & 32.92 \\
\hline
\end{tabular}

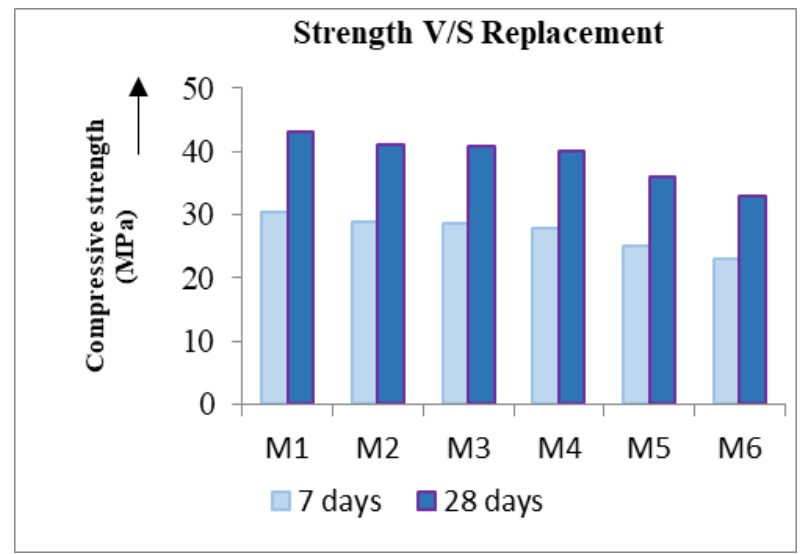

Fig 14. Compressive strength of SCBA-1

Figure 14 shows the variation in the compressive strength for SCBA-1. The results show that the strength of GPC decreased as the percentage of SCBA-1 increased in the rate of $5 \%, 10 \%, 15 \%, 20 \%, 25 \%, 30 \%$. The target strength of specimen for 7 days is $26 \mathrm{MPa}$ but for GPC with $5 \%, 10 \%$, $15 \%, 20 \%$ SCBA-1 it was increased by $17.11 \%, 10.57 \%$, $10.15 \%, 7.42 \%$ respectively. For $25 \%$ and $30 \%$ it was decreased by $3.26 \%$ and $11.30 \%$ respectively. For $5 \%$ replacement of GGBS by SCBA-1 gives highest compressive strength of about $43 \mathrm{MPa}$. The target strength of specimen for 28 days is $38.25 \mathrm{MPa}$ but for GPC with $5 \%, 10 \%, 15 \%, 20 \%$ SCBA-1 it was increased by $12.41 \%, 7.29 \%, 6.92 \%, 4.86 \%$ respectively. For $25 \%$ and $30 \%$ it was decreased by $6.09 \%$ and $13.93 \%$ respectively. It shows that up to $20 \%$, GGBS can be optimally replaced with SCBA-1.

Compressive strength test for GGBS with SCBA-2 based GPC cubes is conducted at $7^{\text {th }}$ and $28^{\text {th }}$ days and the results are tabulated in table 11.

Table 11. Compressive strength test results

\begin{tabular}{|c|c|c|}
\hline Mix ID & 7days & 28days \\
\hline M1 & 30.66 & 44.02 \\
\hline M2 & 29.62 & 42.29 \\
\hline M3 & 28.76 & 41.07 \\
\hline M4 & 28.12 & 40.15 \\
\hline M5 & 27.74 & 39.85 \\
\hline M6 & 25.55 & 36.33 \\
\hline
\end{tabular}

Strength V/S Replacement

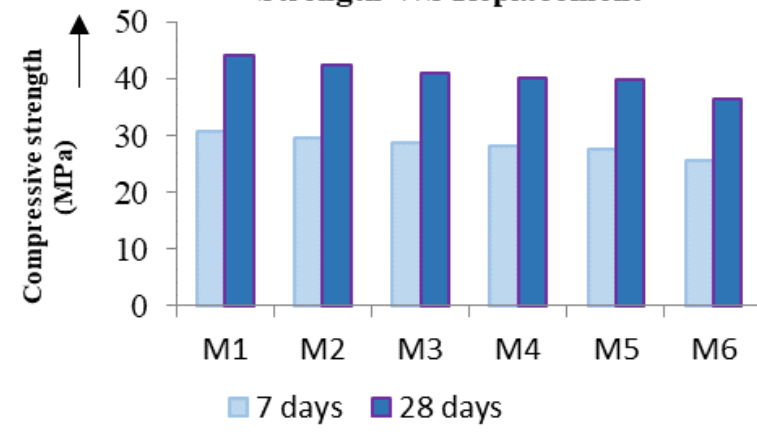

Fig 15. Compressive strength of SCBA-2

Figure 15 shows the variation in the compressive strength for the age of $7^{\text {th }}$ and $28^{\text {th }}$ days for SCBA-2. The target strength of specimen for $7^{\text {th }}$ day is $26 \mathrm{MPa}$ but for GPC with $5 \%, 10 \%, 15 \%, 20 \%, 25 \%$ SCBA-2 it was increased by $17.92 \%, 13.92 \%, 10.61 \%, 8.15 \%, 6.69 \%$ respectively. For $30 \%$ it was decreased by $2.11 \%$. For $5 \%$ GGBS replacement by SCBA-2 gives the highest compressive strength of 44.02 $\mathrm{MPa}$. The target strength of specimen for $28^{\text {th }}$ day is 38.25 MPa but for GPC with 5\%, 10\%, 15\%, 20\%, 25\% SCBA-2 it was increased by $15.08 \%, 10.56 \%, 7.37 \%, 4.96 \%, 4.18 \%$ respectively. For $30 \%$ it was decreased by $5.01 \%$. It is seen that up to $25 \%$, GGBS can be optimally replaced with SCBA-2.

\section{F. Split tensile strength test}

Split tensile strength test for GGBS with SCBA-1and SCBA-2 based GPC cylinders is conducted at $28^{\text {th }}$ days and the results are tabulated in table 12 .

Table 11. Split tensile strength test results

\begin{tabular}{|c|c|c|}
\hline Mix ID & $\begin{array}{c}\text { GGBS with } \\
\text { SCBA-1 based } \\
\text { GPC }\end{array}$ & $\begin{array}{c}\text { GGBS with } \\
\text { SCBA-2 based } \\
\text { GPC }\end{array}$ \\
\hline M1 & 3.33 & 3.48 \\
\hline M2 & 3.25 & 3.36 \\
\hline M3 & 3.2 & 3.27 \\
\hline M4 & 3.18 & 3.2 \\
\hline M5 & 3.02 & 3.14 \\
\hline M6 & 2.82 & 2.89 \\
\hline
\end{tabular}

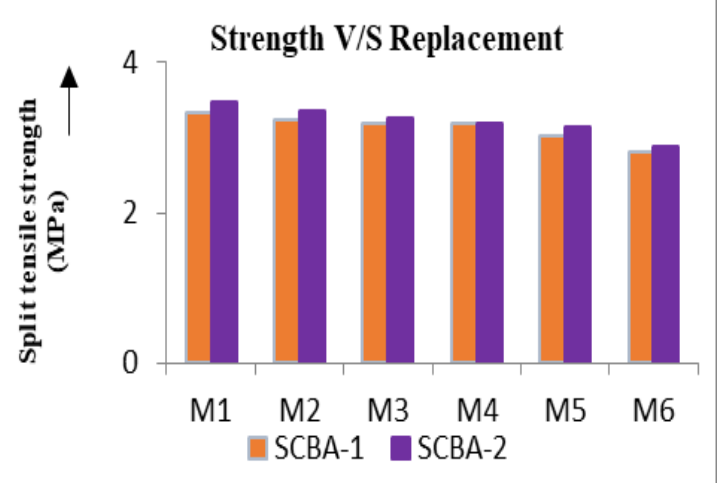

Fig 16. Split tensile strength SCBA-1 and SCBA-2

From figure 16 it can be witnessed that strength of GPC decreased as the 
replacement of SCBA increased in the rate of $5 \%, 10 \%, 15 \%$, $20 \%, 25 \%, 30 \%$ for both sources of SCBA. Comparing the results of both SCBA sources, SCBA- 2 gives better result than SCBA-1. The target strength of specimen for $28^{\text {th }}$ days is $3.06 \mathrm{MPa}$ but for GPC with 5\%, 10\%, 15\%, 20\% SCBA-1 it was increased by $8.82 \%, 6.20 \%, 4.57 \%, 3.92 \%$ respectively. For $25 \%$ and $30 \%$ it was decreased by $1.3 \%$ and $7.84 \%$ respectively. For 5\% partial replacement of GGBS by SCBA-2 gives highest split tensile strength of $3.48 \mathrm{MPa}$. The target strength of specimen for $28^{\text {th }}$ days is $3.06 \mathrm{MPa}$ but for GPC with $5 \%, 10 \%, 15 \%, 20 \%, 25 \%$ SCBA-2 it was increased by $13.72 \%, 9.80 \%, 6.86 \%, 4.57 \%, 2.61 \%$ respectively. For $30 \%$ it was decreased by $5.55 \%$. For varying replacement, the increase in the strength from SCBA-1 to SCBA-2 is $4.5 \%, 3.38 \%, 2.18 \%, 0.62 \%, 3.28 \%, 2.48 \%$ for $5 \%, 10 \%, 15 \%, 20 \%, 25 \%$ and $30 \%$ respectively.

\section{G. Flexural strength test}

Flexural strength test for GGBS with SCBA-1and SCBA-2 based GPC beams is conducted at $28^{\text {th }}$ days and the results are tabulated in table 13 .

Table 13. Split tensile strength test results

\begin{tabular}{|c|c|c|}
\hline Mix ID & $\begin{array}{c}\text { GGBS with SCBA-1 } \\
\text { based GPC }\end{array}$ & $\begin{array}{c}\text { GGBS with SCBA-2 } \\
\text { based GPC }\end{array}$ \\
\hline M1 & 5.73 & 6.02 \\
\hline M2 & 5.25 & 5.57 \\
\hline M3 & 4.88 & 5.06 \\
\hline M4 & 4.26 & 4.33 \\
\hline M5 & 3.66 & 3.92 \\
\hline M6 & 2.62 & 2.72 \\
\hline
\end{tabular}

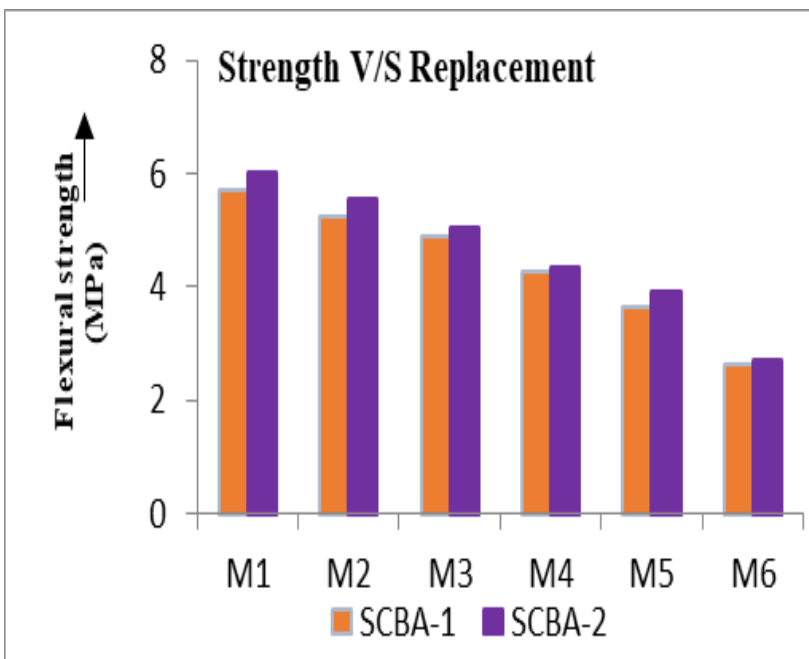

Fig 17. Flexural strength of SCBA-1 and SCBA-2 for 28 days

Figure 17 shows the variation in the flexural strength for both SCBA-1 and SCBA-2 sources. It can be detected that as the percentage replacement of GGBS by SCBA increases the flexural strength decreases gradually. For SCBA-2 the flexural strength obtained is more when compared to SCBA-1. For 5\% replacement of GGBS by SCBA-1 gives highest flexural strength of $5.73 \mathrm{MPa}$. The target strength of specimen for $28^{\text {th }}$ days is $3.80 \mathrm{MPa}$ but for GPC with $5 \%, 10 \%, 15 \%$, $20 \%$ SCBA-1 it was increased by $50.78 \%, 38.15 \%, 28.42 \%$, $12.10 \%$ respectively. For $25 \%$ and $30 \%$ it was decreased by $3.68 \%$ and $31.05 \%$ respectively. For $5 \%$ replacement of GGBS by SCBA-2 gives highest flexural strength of 6.02 $\mathrm{MPa}$. The target strength of specimen for $28^{\text {th }}$ days is 3.80 MPa but for GPC with 5\%, 10\%, 15\%, 20\%, 25\% SCBA-2 it was increased by $58.42 \%, 46.57 \%, 33.15 \%, 13.94 \%, 3.15 \%$ respectively. For $30 \%$ it was decreased by $28.45 \%$. For various replacement, the increase in the strength from SCBA-1 to SCBA-2 is $7.10 \%, 2.67 \%, 3.47 \%, 2.92 \%, 6.95 \%$, $5.34 \%$ for $5 \%, 10 \%, 15 \%, 20 \%, 25 \%$ and $30 \%$ respectively. Strength of GGBS with SCBA-2 GPC is more when compared to GGBS with SCBA-1 GPC.

\section{H. SEM analysis of Geopolymer concrete}

\section{a. SEM analysis of GGBS based SCBA-1 GPC}

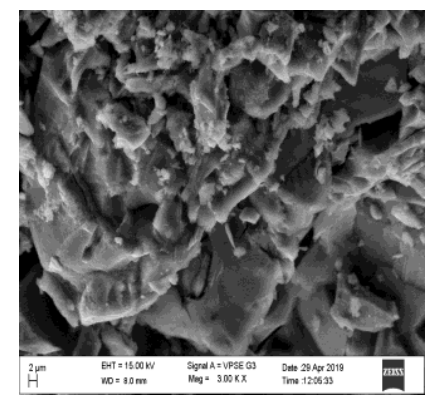

(a)7 days

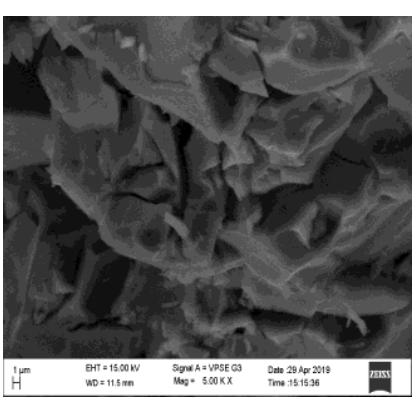

(b) 28 days
Fig 18. SEM images GGBS based SCBA-1 GPC

Figure 18 shows the micrographs of $5 \%$ SCBA-1+ 95\%GGBS for $7^{\text {th }}$ and $28^{\text {th }}$ days taken by SEM technique. In figure 18 (a) the micrographs of 5\%SCBA-1+95\%GGBS shows heterogeneous matrix. At $28^{\text {th }}$ day as in figure $18(\mathrm{~b})$ the concrete is observed to be denser and seen like crystalline structure. It is seen that ITZ thickness reduced for 28 days.

\section{b. SEM analysis of GGBS based SCBA-2 GPC}

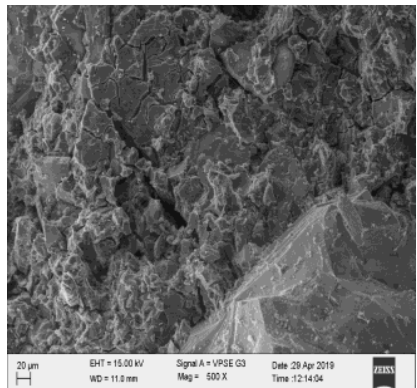

(a)7 days

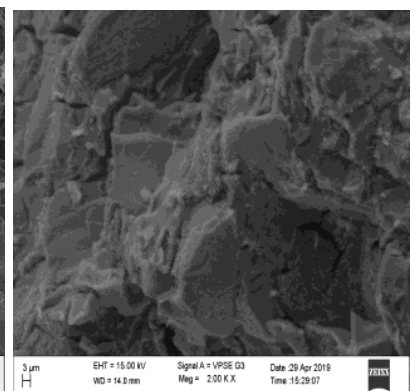

(b) 28 days
Fig 19. SEM images GGBS based SCBA-2 GPC

Figure 19 shows the micrographs of $5 \%$ SCBA-2+ $95 \%$ GGBS for $7^{\text {th }}$ and $28^{\text {th }}$ days taken by SEM technique. In figure 19 (a) the micrographs of $5 \%$ SCBA-2+95\%GGBS shows discontinuous in the interphase between aggregate and the pozzolanic

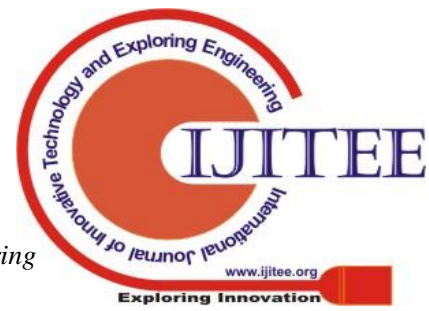




\section{Micro-behavioral study of Bagasse ash based Geopolymer concrete}

materials like GGBS and BA. At 28 days as in figure 19(b) the concrete is observed to be denser. And ITZ thickness reduced for 28 days.

\section{CONCLUSION}

1. GGBS based SCBA geopolymer concrete are less workable. As the inclusion of SCBA increased, the workability of the concrete decreased.

2. From different sources of SCBA, the sources of SCBA which has highest silica content is considered by XRF technique. It is found that SCBA-2 contains the highest silica content than SCBA-1.

3. For both sources of SCBA, micro structural analysis is carried out by XRF, XRD, SEM, EDS and from these tests, the chemical composition of SCBA samples, mineralogical examination of SCBA, morphology of SCBA and elemental composition is determined and studied. The morphology of SCBA-2 sample shows particles are denser and contains amorphous silica as compared to SCBA-1 sample.

4. It is observed that the strength for SCBA-2 based GPC is more when compared to SCBA-1 based GPC, this is because SCBA-2 contains high silica content than SCBA-1.

5 . It is observed that for $5 \%$ replacement of GGBS by SCBA gives highest compressive strength for both SCBA sources. SCBA-1 at $20 \%$ replacement has shown the optimum percentage for best results for GPC. SCBA-2 at $25 \%$ replacement has shown the optimum percentage for best results for GPC.

6. It is concluded that SCBA can be used to replace GGBS in order to produce eco-friendly concrete. Because both GGBS and SCBA are waste materials from steel plants and sugar factories respectively.

\section{ACKNOWLEDGEMENTS}

The authors wish to thank Dr. N. Suresh for giving his valuable guidance for the research work and the company $\mathrm{L} \&$ $\mathrm{T}$ CTEA for providing the lab facilities to conduct the experimental work. Also thanking to JSW cements for supplying GGBS which is very necessary for the experimental work.

\section{REFERENCES}

1. Dattatreya J K, Rajamane N P, Sabitha D, Ambily P S, Nataraja M, "Flexural behaviour of reinforced Geopolymer concrete beams," International Journal of Civil and Stuctural Engineering, 2011.

2. Dilip Srinivas, Madankumar L, Madhusudan R, Dilipkumar N V and Sumantha S, "Feasibility analysis of use of Bagasse ash for the production of Geo polymer concrete," International Journal of Engineering Research and Tehnaology, 2017.

3. Mandeep Raj N, Y Umashankar Shetty, "Experimental Study on Bagasse Ash Concrete," International Journal of Innovative Research in Science, Engineering and Technology, pp. 2347-6710, 2016.

4. Sachin Mulay, Gaurang Vesmawala, Yogesh Patil, Vikas Gholap, "Experimental Investigation of Sugarcane Bagasse Ash Concrete Under Sodium Hydroxide Solution," American Journal of Civil Engineering, pp.1-8, 2017.

5. Sourav Kr Das, Amarendra Kr Mohapatra, A K Rath, "Geo-polymer Concrete-Green Concrete for the future- A Review," International Journal of Civil Engineering Research, pp. 21-28, 2014.

6. Tony Suman Kanth D, K U Muthu, "Hardened Properties of Bagasse Ash GPC and Rice-husk Ash GPC," International Journal of Innovative Research in Science, Engineering and Technology, pp. 2347-6710, 2015.
7. Vinicius N Castaldelli, Jorge L Akasaki, Jose L P Melges, Mauro M Tashima, Lourdes Soriano, Maria V Borrachero, Jose Manzo, JordiPaya, "Use of Slag/Sugar Cane Bagasse Ash (SCBA) Blends in the Production of Alkali-Activated Materials", Materials (Basel), pp 3108-3127, 2013.

\section{AUTHORS PROFILE}

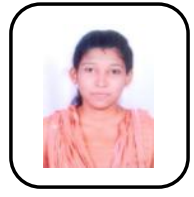

Savitha $\mathbf{T} \mathbf{M}$, is pursuing $\mathbf{M}$. Tech. degree in Structural Engineering from National Institute of Engineering (NIE), Mysore, Karnataka, 570008, India. She completed her B.E. degree in Civil Engineering in 2017 from P.E.S.College of Engineering, Mandya, India. Her research interests include Geopolymer concrete. savithamadikeri1996@gmail.com

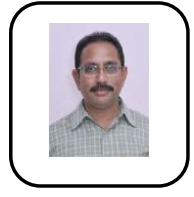

Dr. Y. M. Manjunath, is working as a Professor in Department of Civil Engineering, National Institute of Engineering (NIE), Mysore, Karnataka, 570008 , India. He obtained the Ph.D. degree in 2011 from Kuvempu University, Karnataka and M.Tech. degree in Industrial Structures from University of Mysore in 1991.

Ymm65_nie@yahoo.co.in

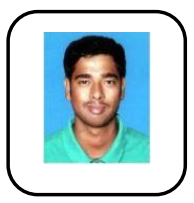

Dilip Srinivas, working as Assistant Manager in L \& T CTEA, Mysore, Karnataka, India.he is currently pursuing Ph.D. degree at VTU, Belgaum. dilipsrinivas1989@gmail.com 